\title{
Contamination of Water, Dust, Soil, Rock and Urine with Fluoride in Central India
}

\author{
Khageshwar Singh Patel1*, Dhananjay Sahu1, Nohar Singh Dahariya1, Bharat Lal Sahu1, \\ Shobhana Ramteke1, Borislav Blazhev' ${ }^{2}$, Laurent Matini ${ }^{3}$, Eduardo Yubero ${ }^{4}$, Jan Hoinkis ${ }^{5}$ \\ ${ }^{1}$ School of Studies in Chemistry/Environmental Science, Pt. Ravishankar Shukla University, Raipur, India \\ ${ }^{2}$ Central Laboratory for Chemical Testing and Control, Sofia, Bulgaria \\ ${ }^{3}$ Department of Exact Sciences, Marien Ngouabi University, Brazzaville, Congo \\ ${ }^{4}$ Applied Physics Department, Miguel Hernandez University, Elche, Spain \\ ${ }^{5}$ Karlsruhe University of Applied Sciences, Karlsruhe, Germany \\ Email: "patelkhageshwarsingh@gmail.com
}

Received 22 October 2015; accepted 4 December 2015; published 7 December 2015

Copyright (C) 2015 by authors and Scientific Research Publishing Inc.

This work is licensed under the Creative Commons Attribution International License (CC BY).

http://creativecommons.org/licenses/by/4.0/

c) (i) Open Access

\section{Abstract}

At least 15\% of 0.1 million people residing in 117 villages of Tamnar block (Chhattisgarh, central India) are suffering from fluorosis diseases. In this work, the contamination of $F^{-}$in the environment (i.e. water, soil, rock and urine) of the Tamnar block is described. The concentration variations of $\mathrm{F}^{-}, \mathrm{Cl}^{-}, \mathrm{NO}_{3}^{-}, \mathrm{SO}_{4}^{2-}, \mathrm{Na}^{+}, \mathrm{K}^{+}, \mathrm{Mg}^{2+}, \mathrm{Ca}^{2+}, \mathrm{Al}, \mathrm{Mn}, \mathrm{Fe}$ and $\mathrm{Zn}$ in the groundwater are reported. The $\mathrm{F}^{-}$content in the water was ranged from $1.7-17 \mathrm{mg} / \mathrm{L}$ with mean value of $9.0 \pm 3.7 \mathrm{mg} / \mathrm{L}$. Fluoride was enriched up to 3-, 54-, 69- and 244-folds in the urine, soil, dust and rock, respectively. The cluster and factor analysis models were used to apportion sources of $F^{-}$and other elements in the water.

\section{Keywords}

Fluoride, Contamination, Groundwater, Soil, Rock, India

\section{Introduction}

Fluorine is a highly reactive element, and it has an important role in precipitation of various elements as minerals [1]. Fluorine contents in the soil vary between $10-150 \mathrm{mg} / \mathrm{kg}$, and the majority of fluorine occurs naturally in combined forms in various rocks, soils, waters, plants, other living organisms, slag, fluxes, etc. The fluoride

${ }^{*}$ Corresponding author.

How to cite this paper: Patel, K.S., Sahu, D., Dahariya, N.S., Sahu, B.L., Ramteke, S., Blazhev, B., Matini, L., Yubero, E. and Hoinkis, J. (2015) Contamination of Water, Dust, Soil, Rock and Urine with Fluoride in Central India. Journal of Environmental Protection, 6, 1347-1359. http://dx.doi.org/10.4236/jep.2015.612117 
in the ground water is severely extracting from the bed rock causing a disease known as "fluorosis", which continues to be an endemic problem in most parts of the world [2]. India is among the 23 nations around the globe, where fluorosis health problems (i.e. dental, skeletal and/or non-skeletal) are continuing to exist mainly due to the consumption of contaminated water [3]-[21]. Most of the minerals and coal of the country are reserved in the Chhattisgarh state, India. The vast exploitation of the natural resources and overuse of ground water leads to depletion of the ground water quality in several parts of the state [22]-[23]. The endemic fluoride toxicity in the Tamnar block, India has been observed [24].

Therefore, in this work, concentration, variation and sources of $\mathrm{F}^{-}$in the ground water, urine, dust, surface soil and rock of the Tamnar block (Raigarh, CG, India) are described for the evaluation of the risks associated with the water, dust and soil exposures.

\section{Materials and Methods}

\subsection{Study Area}

Tamnar block includes Tamnar town and 116 villages with population of 0.1 million, situated in the Raigarh district, Chhattisgarh, India. The area of the Tamnar block is $\approx 250 \mathrm{~km}^{2}\left(22^{\circ} 05^{\prime} \mathrm{N}-22^{\circ} 15^{\prime} \mathrm{N}\right.$ and $83^{\circ} 20^{\prime} \mathrm{E}-$ $\left.83^{\circ} 30^{\prime} \mathrm{E}\right)$. It lies at an elevation of $215 \mathrm{~m}$ above sea level, situated in a passing point of the Kelo River. $\mathrm{A} \approx 285$ MT coal is reserved in this area and an open cast mine of capacity $\approx 5.25 \mathrm{MT}$ coal/Yr is in operation. The thermal power plant of capacity, $600 \mathrm{MW}$ is running by pouring the industrial effluents in the environment. The area is composed of Gondwana subgroup of rocks consisting of sand stone, shale, carbonaceous shale, clay and coal seams. These rocks were subjected to deformation and crustal movement during Paleozoic times with evidence of folding and faulting.

\subsection{Sample Collection}

Twenty two groundwater samples from 6 villages (i.e. Bandhapali, Dholnara, Kunjemura, Mudagaon, Pata and Saraitola) were collected during pre and post monsoon period of years, 2008 - 2012 as prescribed in the literature [25]. The sampling locations are shown in Figure 1. The road dust, surface soil $(0-10 \mathrm{~cm}$ depth $)$ and stone from six villages (i.e. Bandhapali, Dholnara, Kunjemura, Mudagaon, Pata and Saraitola) were collected in the post monsoon period, December 2008 [26]. The first morning urine sample $(100 \mathrm{~mL})$ was collected in plastic bottles containing $0.2 \mathrm{~g}$ EDTA in year 2008. Total $36(6 \times 1 \times 6))$ urine samples of human, cattle, buffalo, sheep and goat were collected and shipped to the laboratory in insulated container and stored at $-20^{\circ} \mathrm{C}$ until use.

\subsection{Sample Preparation}

The groundwater sample was collected into cleaned 1-L polyethylene container. The sample was divided into two portions. The $1^{\text {st }}$ portion was used for analysis of physical parameters, ammonia and anions. The $2^{\text {nd }}$ portion was acidified with a few drops of ultrapure nitric acid (E. Merck) for the analysis of metals. All water samples were refrigerated at $4^{\circ} \mathrm{C}$. The soil samples were dried, crushed and sieved out of particles of mesh size $<0.1 \mathrm{~mm}$. A $5.00 \mathrm{~g}$ soil sample was mixed with $50 \mathrm{~mL}$ of hot $\left(50^{\circ} \mathrm{C}\right)$ deionized water in an ultrasonic bath for $6 \mathrm{hr}$. The extract was used for the measurement of the $\mathrm{pH}$ and ions. A weighed amount of crushed granite sample $(0.25 \mathrm{~g})$ was placed in a $50 \mathrm{ml}$ Pt-crucible by adding $2.0 \mathrm{~g} \mathrm{NaOH}$ [27]. The crucible was kept in a muffle furnace and slowly raising the temperature up to $600^{\circ} \mathrm{C}$. The sample was fused up to $30 \mathrm{~min}$, and the residue was dissolved with hot water. The $\mathrm{pH}$ of the extract was adjusted to 9.0 to precipitate the interfering ions i.e. $\mathrm{Fe}, \mathrm{Al}, \mathrm{Mn}$. Then, it was filtered and diluted to $100 \mathrm{~mL}$ in a polyethylene volumetric flask for the $\mathrm{F}^{-}$analysis.

\subsection{Analysis}

The physical parameters i.e. temperature (T), $\mathrm{pH}$, dissolved oxygen (DO), reduction potential (RP) and electrical conductivity (EC) values were determined by HANNA made sensors. The total dissolved solid (TDS) value was determined by evaporation of the filtered water sample (through glass fiber filter) by drying at constant weight [28]. The $\mathrm{F}^{-}$content was monitored with Metrohm ion meter-781, equipped with fluoride ion selective electrode and calomel electrode. The ion meter was calibrated with the standard solution over range of $2.0-25.0 \mathrm{mg} / \mathrm{L} \mathrm{F}^{-}$ containing acetate buffer into 1:1 volume ratio $(58 \mathrm{~g} \mathrm{NaCl}$ and $57 \mathrm{~mL}$ acetic acid with de-ionized water and 


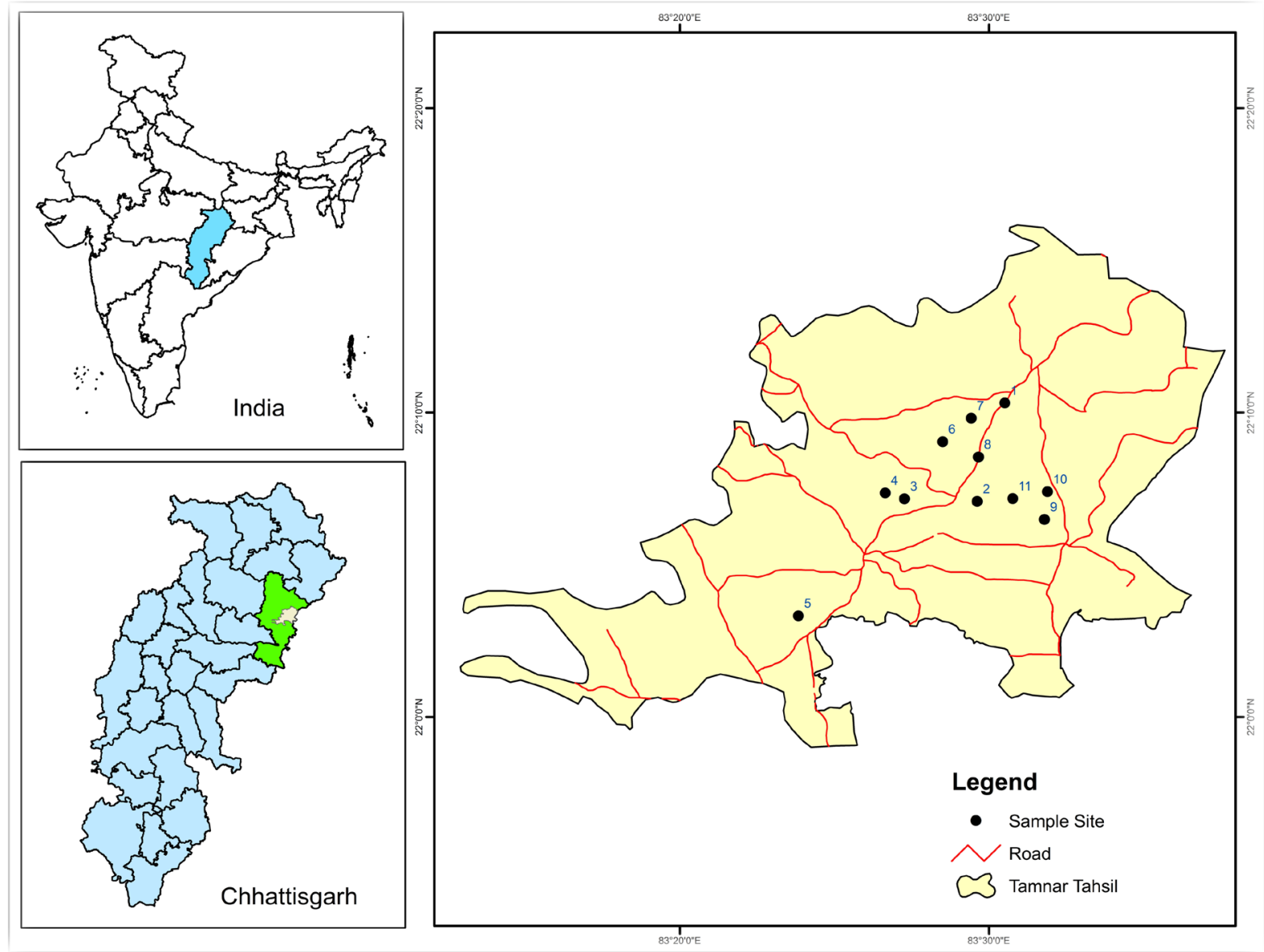

Figure 1. Representation of sampling locations.

neutralized with $5 \mathrm{M} \mathrm{NaOH}$ solution to the pH value of 5.5 into final dilution of 1 liter). Similarly, $10 \mathrm{~mL}$ of the sample solution was mixed with $10 \mathrm{~mL}$ buffer in a $50-\mathrm{mL}$ plastic beaker in a 1:1 volume ratio and $\mathrm{F}^{-}$content was monitored. The content of $\mathrm{Cl}^{-}, \mathrm{NO}_{3}^{-}, \mathrm{SO}_{4}^{2-}, \mathrm{Na}^{+}, \mathrm{K}^{+}, \mathrm{Mg}^{2+}$ and $\mathrm{Ca}^{2+}$ was analyzed by Dionex-DX1100 ion chromatography, equipped with anion and cation separation columns and conductivity detector. The hardness and alkalinity were determined by the titration methods [29]. The metals were analyzed with the AA280FS atomic absorption spectrophotometer, equipped with VGA-77 (plasma flow: $15 \mathrm{~L} / \mathrm{min}$, auxiliary flow: $1.5 \mathrm{~L} / \mathrm{min}$, power: 1KW, PMT voltage: $650 \mathrm{~V}$ ).

Multivariate statistical analysis such as factor analysis (FA) and hierarchical cluster analysis (HCA) were used for the source apportionments [30]-[32]. The statistical Windows software STATISTICA 7.1 was employed for the multivariate statistical calculations. The enrichment factor (Ef) was determined by using $\mathrm{Al}$ as reference metal [33].

\section{Results and Discussion}

\subsection{Physical Characteristics of Tube Well}

The physical parameters of the tube well and groundwater are summarized in Table 1. The depth and life of tube well $(n=11)$ was varied from $70-156 \mathrm{~m}$ and $2.0-21 \mathrm{Yr}$ with mean value of $106 \pm 20 \mathrm{~m}$ and $7.7 \pm 3.0 \mathrm{Yr}$, respectively. The temperature and $\mathrm{pH}$ values of groundwater of 11 tube wells were ranged from $30.7^{\circ} \mathrm{C}-35.8^{\circ} \mathrm{C}$ and $6.4-7.5$ with mean value of $33.0^{\circ} \mathrm{C} \pm 1.0^{\circ} \mathrm{C}$ and $7.1 \pm 0.2$, respectively. The pH value of all groundwater was found to be neutral due to higher content of ions i.e. $\mathrm{Mg}^{2+}, \mathrm{Ca}^{2+}, \mathrm{HCO}_{3}^{-}$and $\mathrm{CO}_{3}^{2-}$. The $\left.\left[\Sigma_{\text {anion }}\right] / \Sigma_{\text {cation }}\right]$ ratio was ranged from $0.89-1.28$ with a mean value of $1.1 \pm 0.1$. The increasing $\mathrm{T}$ value of the water with respect to tube well depth was marked due to the geothermal energy, Figure 2. The DO value of the water was 


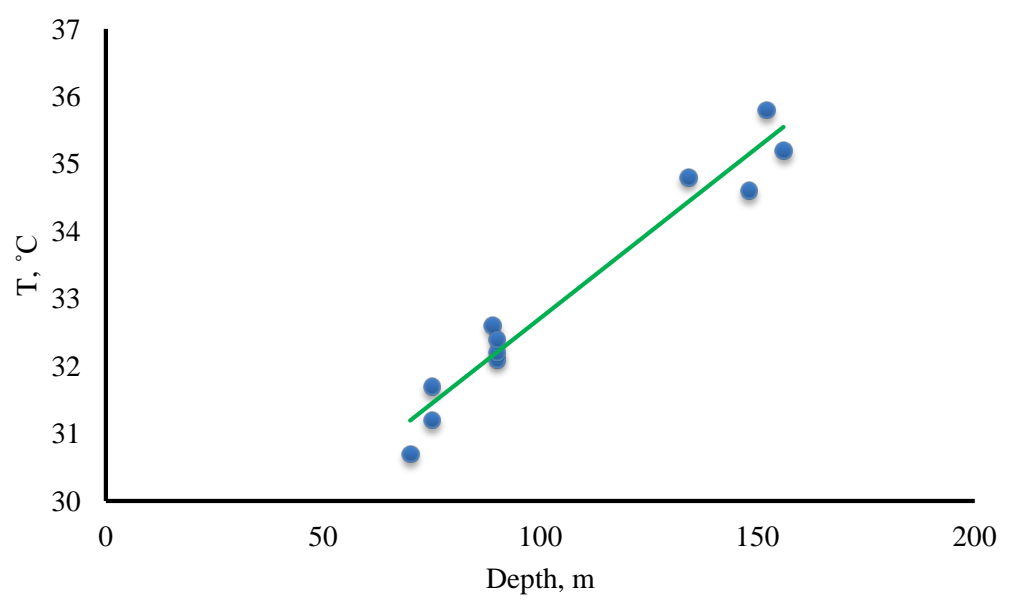

(a)

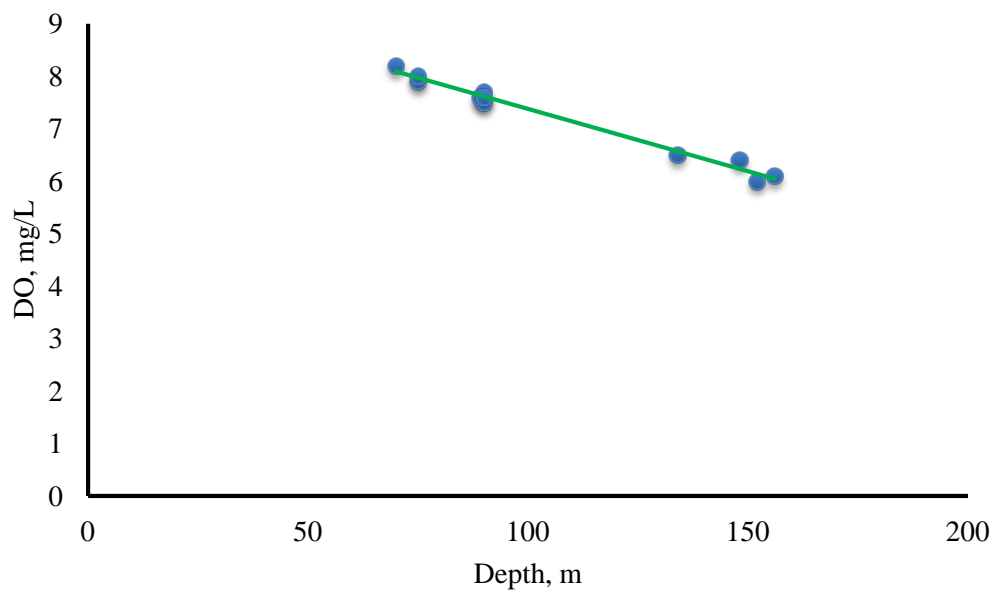

(b)

Figure 2. Correlation of tube well depth profile with the T and DO of the water.

Table 1. Geophysical characteristics of water and tube well.

\begin{tabular}{cccccccccc}
\hline S. No. & Location & $\begin{array}{c}\text { Depth of tube } \\
\text { well, } \mathrm{m}\end{array}$ & $\begin{array}{c}\text { Life of tube } \\
\text { well, } \mathrm{Yr}\end{array}$ & $\begin{array}{c}\text { Water } \\
\text { table, } \mathrm{m}\end{array}$ & $\mathrm{T},{ }^{\circ} \mathrm{C}$ & $\mathrm{pH}$ & $\mathrm{DO}, \mathrm{mg} / \mathrm{L}$ & $\mathrm{RP}, \mathrm{mV}$ \\
\hline 1 & Dholnara & 70 & 9 & 10 & 30.7 & 6.4 & 8.2 & 169 \\
2 & Kunjemura & 90 & 10 & 11 & 32.1 & 7.5 & 7.7 & 167 & 149 \\
3 & Pata & 75 & 12 & 15 & 31.2 & 7.3 & 7.9 & 7.5 & 155 \\
4 & Pata & 90 & 6 & 15 & 32.2 & 7.5 & 7.5 & 149 \\
5 & Bandhapali & 89 & 6 & 16 & 32.6 & 7.3 & 7.6 & & 145 \\
6 & Mudagaon & 75 & 21 & 18 & 31.7 & 6.9 & 8.0 & 168 \\
7 & Mudagaon & 156 & 9 & 16 & 35.2 & 7.1 & 6.1 & 158 \\
8 & Mudagaon & 134 & 3 & 16 & 34.8 & 7.3 & 6.5 & 163 \\
9 & Saraitola & 148 & 3 & 20 & 34.6 & 6.9 & 6.4 & 168 \\
10 & Saraitola & 90 & 4 & 19 & 32.4 & 6.8 & 7.6 & 170 \\
11 & Saraitola & 152 & 2 & 20 & 35.8 & 6.9 & 6.0 & 169 \\
\hline
\end{tabular}


ranged from 6.0 - $8.2 \mathrm{mg} / \mathrm{L}$ with mean value of $7.2 \pm 0.8 \mathrm{mg} / \mathrm{L}$. The higher DO value of the water than the recommended value of $4.0 \mathrm{mg} / \mathrm{L}$ was observed, may be due to dense vegetation coverage. The DO value was found to decrease with respect to depth profile of the tube well, Figure 2. However, the T and DO value of the water was found to be negatively $(\mathrm{r}=-0.57)$ and positively $(\mathrm{r}=0.58)$ correlated with the life of the tube well, respectively, Figure 3. The lower RP value of the water of the studied area was recorded, ranging from $145-170 \mathrm{mV}$ with mean value of $162 \pm 5 \mathrm{mV}$, being $\approx<3.5$-folds less than recommended value of $600 \mathrm{mV}$. The EC and TDS values of the water was ranged from $316-576 \mu \mathrm{S} / \mathrm{cm}$ and $193-499 \mathrm{mg} / \mathrm{L}$ with mean value of $391 \pm 51 \mu \mathrm{S} / \mathrm{cm}$ and $312 \pm 54 \mathrm{mg} / \mathrm{L}$, respectively. The EC value was found to be well correlated with the TDS and total ionic concentration $(r=0.92-0.97)$, Figure 4 .

\subsection{Chemical Characteristics of Groundwater}

The concentration of $\mathrm{F}^{-}$and other elements in the ground water of the Tamnar block $(\mathrm{n}=11)$ during post monsoon period (December, 2008) is summarized in Tables 2-3. The value of $\mathrm{HCO}_{3}^{-}, \mathrm{CO}_{3}^{2-}$, TH and TA was ranged from 121 - 302, 0.9 - 6.6, 61 - 218 and 159 - $397 \mathrm{mg} / \mathrm{L}$ with mean value of $190 \pm 30,2.4 \pm 1.3,102 \pm 27$ and $250 \pm 40$, respectively. The concentration of $\mathrm{F}^{-}, \mathrm{Cl}^{-}, \mathrm{NO}_{3}^{-}, \mathrm{SO}_{4}^{2-}, \mathrm{NH}_{4}^{+}, \mathrm{Na}^{+}, \mathrm{K}^{+}, \mathrm{Mg}^{2+}, \mathrm{Ca}^{2+}, \mathrm{Al}, \mathrm{Fe}, \mathrm{Mn}$ and Zn was ranged from 0.7 - 17.3, 6.0 - 61, 2.8 - 9.2, 0.5 - 39, 1.2 - 4.6, 5.9 - 43, 6.3 - 32, 6.6 - 25, 11 - 50, 0.28 - 0.34, $1.4-13,0.07-0.26$ and $0.8-1.7 \mathrm{mg} / \mathrm{L}$ with mean value of $9.0 \pm 3.8,18 \pm 9,6.0 \pm 13,6.7 \pm 6.7,2.6 \pm 0.6,30 \pm 7$, $15 \pm 5,12 \pm 4,21 \pm 7,0.30 \pm 0.01,5.6 \pm 2.4,0.16 \pm 0.03$ and $1.17 \pm 0.19 \mathrm{mg} / \mathrm{L}$, respectively. The metals i.e. K, $\mathrm{Mg}, \mathrm{Ca}, \mathrm{Fe}, \mathrm{Mn}$ and $\mathrm{Zn}$ were highly enriched in the water with Ef value of $135 \pm 55,259 \pm 71,197 \pm 60,43 \pm$ $18,90 \pm 20,152 \pm 24$ and $100 \pm 20$, respectively.

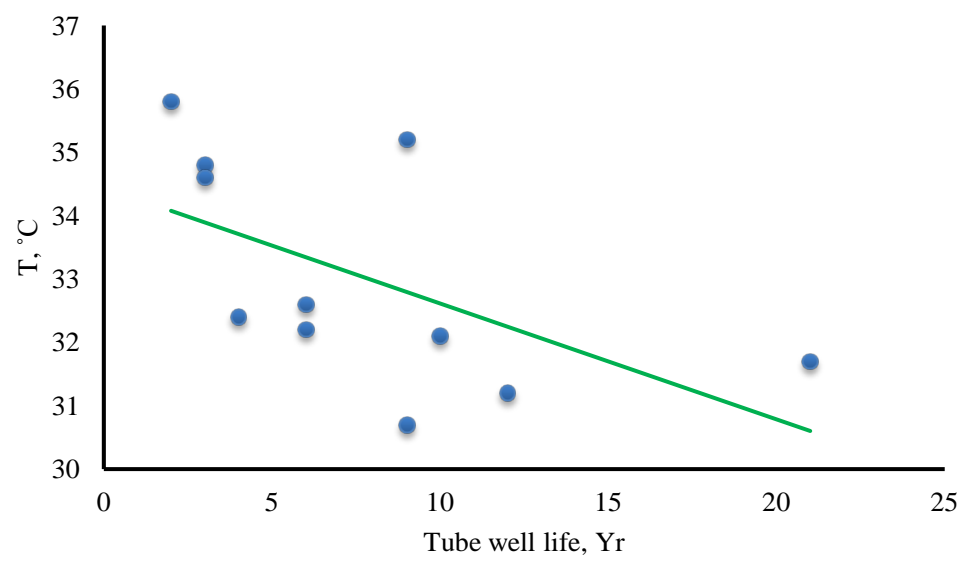

(a)

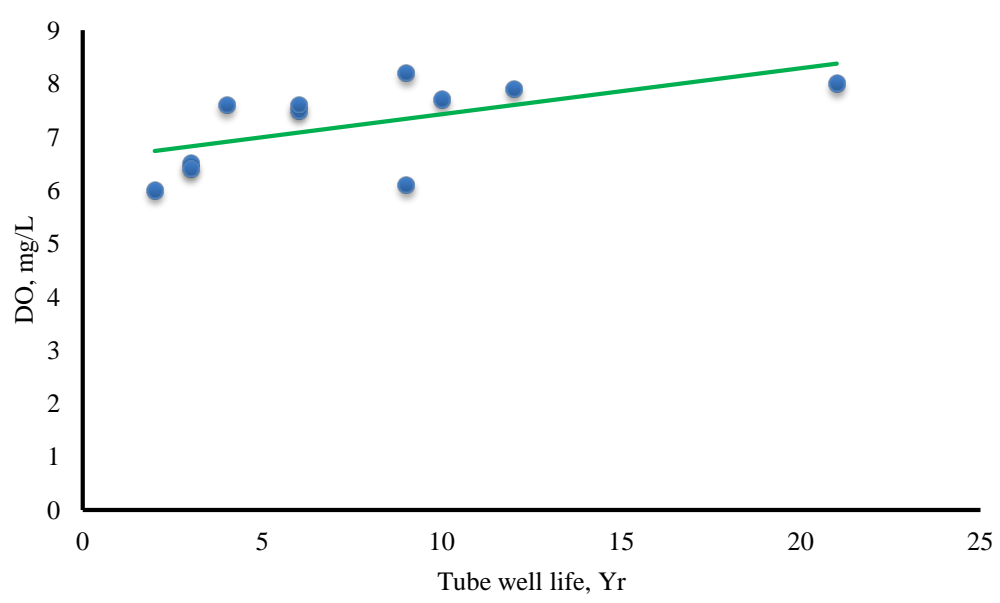

(b)

Figure 3. Correlation of tube well life with the T and DO of the water. 


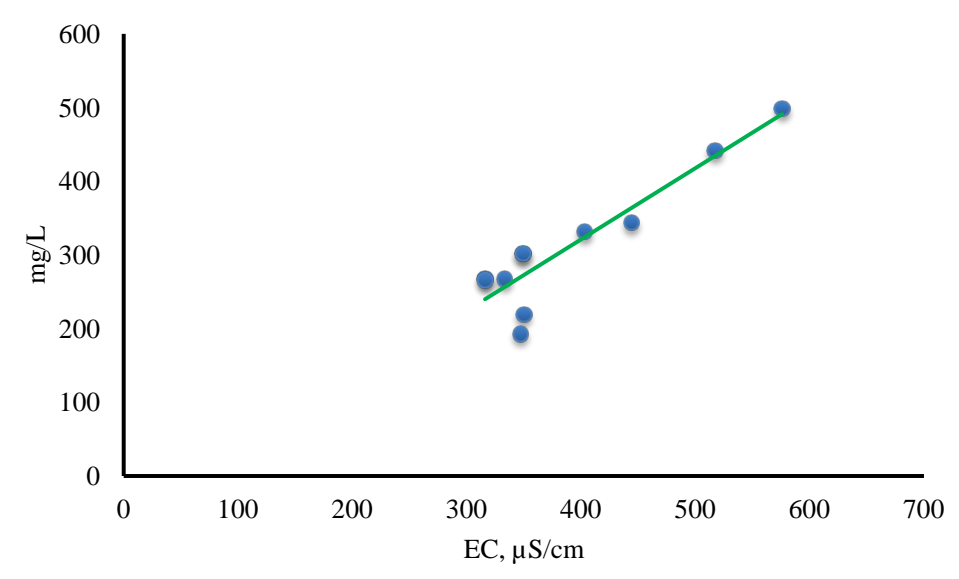

Figure 4. Correlation of EC and [ $\left.\Sigma_{11 \text { ions }}\right]$.

Table 2. Chemical characteristics of groundwater during post monsoon period, 2008, mg/L.

\begin{tabular}{cccccccccccc}
\hline S. No. & $\mathrm{EC}, \mu \mathrm{S} / \mathrm{cm}$ & $\mathrm{TDS}$ & $\mathrm{TA}$ & $\mathrm{TH}$ & $\mathrm{F}^{-}$ & $\mathrm{Cl}^{-}$ & $\mathrm{NO}_{3}^{-}$ & $\mathrm{SO}_{4}^{2-}$ & $\mathrm{HCO}_{3}^{-}$ & $\mathrm{CO}_{3}^{2-}$ \\
\hline 1 & 347 & 396 & 159 & 90 & 1.7 & 6.7 & 4.1 & 12 & 121 & 1.2 \\
2 & 349 & 492 & 272 & 105 & 2.2 & 13.9 & 5.4 & 0.8 & 208 & 1.5 \\
3 & 517 & 716 & 397 & 145 & 3.1 & 13.5 & 7.3 & 4.5 & 302 & 3.3 \\
4 & 444 & 568 & 270 & 124 & 3.8 & 18.8 & 8.5 & 4.3 & 201 & 6.6 \\
5 & 576 & 806 & 317 & 218 & 2.8 & 61.3 & 8.3 & 39 & 242 & 1.5 \\
6 & 333 & 450 & 210 & 61 & 10.1 & 16.7 & 2.8 & 5.1 & 161 & 0.9 \\
7 & 403 & 535 & 270 & 82 & 13.4 & 16.6 & 6.7 & 0.5 & 201 & 6.6 \\
8 & 349 & 491 & 246 & 71 & 17.3 & 14.9 & 5.8 & 0.6 & 188 & 1.2 \\
9 & 316 & 443 & 211 & 78 & 13.2 & 13.6 & 9.2 & 5.9 & 161 & 1.5 \\
10 & 350 & 494 & 176 & 62 & 16.7 & 6.0 & 4.3 & 0.9 & 134 & 1.2 \\
11 & 316 & 399 & 220 & 81 & 14.3 & 11.7 & 3.1 & 0.5 & 168 & 1.2 \\
\hline
\end{tabular}

Table 3. Concentration of cations and metals in groundwater during post monsoon period, 2008, mg/L.

\begin{tabular}{ccccccccccc}
\hline S. No. & $\mathrm{NH}_{4}^{+}$ & $\mathrm{Na}^{+}$ & $\mathrm{K}^{+}$ & $\mathrm{Mg}^{2+}$ & $\mathrm{Ca}^{2+}$ & $\mathrm{Al}$ & $\mathrm{Fe}$ & $\mathrm{Mn}$ & $\mathrm{Zn}$ \\
\hline 1 & 1.6 & 5.9 & 7.4 & 9.9 & 21 & 0.29 & 3.9 & 0.11 & 1.1 \\
2 & 2.3 & 13 & 18 & 14 & 23 & 0.29 & 3.9 & 0.16 & 1.3 \\
3 & 3.5 & 30 & 22 & 21 & 32 & 0.29 & 3.2 & 0.16 & 1.5 \\
4 & 3.1 & 24 & 32 & 14 & 28 & 0.30 & 7.2 & 0.22 & 1.6 \\
5 & 2.7 & 39 & 27 & 25 & 50 & 0.31 & 3.4 & 0.26 & 1.7 \\
6 & 1.2 & 42 & 7.8 & 7.7 & 12 & 0.34 & 13 & 0.07 & 0.9 \\
7 & 2.4 & 43 & 16 & 11 & 15 & 0.28 & 1.4 & 0.18 & 1.0 \\
8 & 1.7 & 41 & 11 & 8.0 & 12 & 0.29 & 4.0 & 0.15 & 0.9 \\
9 & 1.9 & 33 & 6.3 & 8.8 & 14 & 0.28 & 6.4 & 0.21 & 1.0 \\
10 & 4.6 & 26 & 7.2 & 6.6 & 11 & 0.29 & 13 & 0.15 & 0.8 \\
11 & 3.1 & 30 & 11 & 8.7 & 14 & 0.29 & 2.1 & 0.10 & 0.8 \\
\hline
\end{tabular}


The increased content of $\mathrm{F}^{-}$and other ions was found in the deeper tube wells lie along the Digi Nala (stream) due to the higher weathering. The content of $\mathrm{F}^{-}$and other elements (except $\mathrm{NO}_{3}^{-}, \mathrm{NH}_{4}^{+}$and $\mathrm{K}^{+}$) was enhanced from the monsoon to pre monsoon period, may be due to decreasing of the water level (up to $\approx 50 \mathrm{~m}$ ) and increasing of water temperature (up to $\approx 35^{\circ} \mathrm{C}$ ) (Figure 5). The temporal variation in the ion and metal contents during post monsoon period of year 2008-2012 is presented in Figure 6. The concentration of most of the chemical species was enhanced at the rate of $>5 \%$, may be due to increasing anthropogenic activities viz. coal mining, coal burning, transportation, agriculture, etc. in this region.

The Ward's method was used for grouping of groundwater dataset. Three cluster groups-I (observations 3 and 5), group-II (observations 2, 4, 6 - 9 and 11) and group-III (1 and 10) are presented in Figure 7. The discriminating parameters observed were $\mathrm{EC}, \mathrm{TDS}, \mathrm{Fe}, \mathrm{Mn}, \mathrm{K}^{+}, \mathrm{F}^{-}, \mathrm{Cl}^{-}, \mathrm{SO}_{4}^{2-}, \mathrm{NO}_{3}^{-}$and alkalinity. The parameters such as life of tube well, $\mathrm{Mg}^{2+}, \mathrm{Ca}^{2+}$ and hardness had the higher median value in the group-I than the group-II and -III.

Factor analysis was executed on 22 variables for the 11 sample sites, in order to identify factors controlling the groundwater quality. In reference to the Eigenvalues, five factors were extracted after varimax rotation as they had eigenvalues greater than 1 . The variable loading, eigenvalues, explained variance and cumulative variance are presented in Table 4. Calcium, chloride or sulfate with positive strong loading values, and hardness or TDS with moderate loading values in factor-I characterized the inorganic salts and groundwater hardness due to bicarbonates and carbonates. Life of tube well and $\mathrm{Al}$ contents had a strong loading value in factor-II. Aluminum content in groundwater was seemed to be more important if the life of tube well was high. Parameters i.e. water table, sodium and fluoride content had strong loading values in factor-III, which could be related to cation

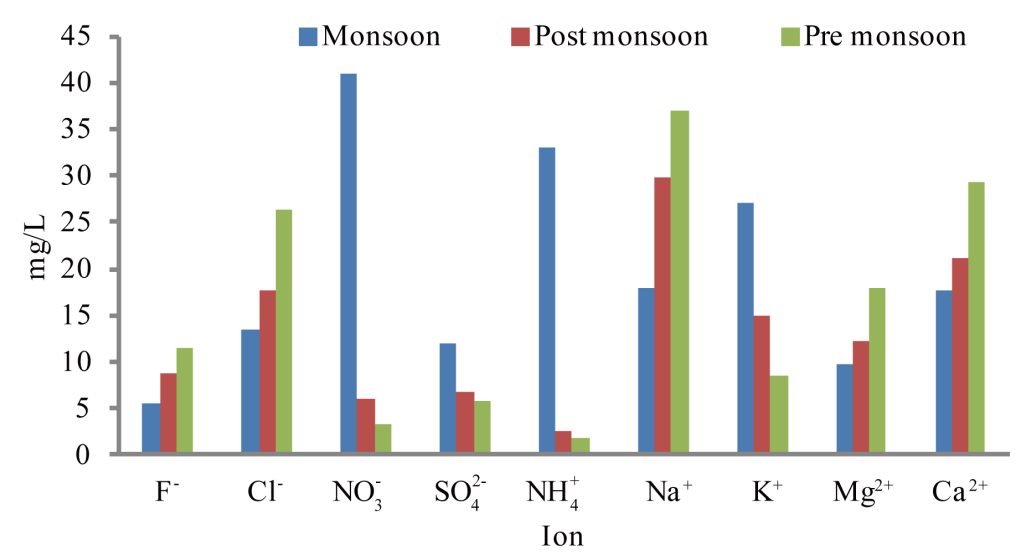

(a)

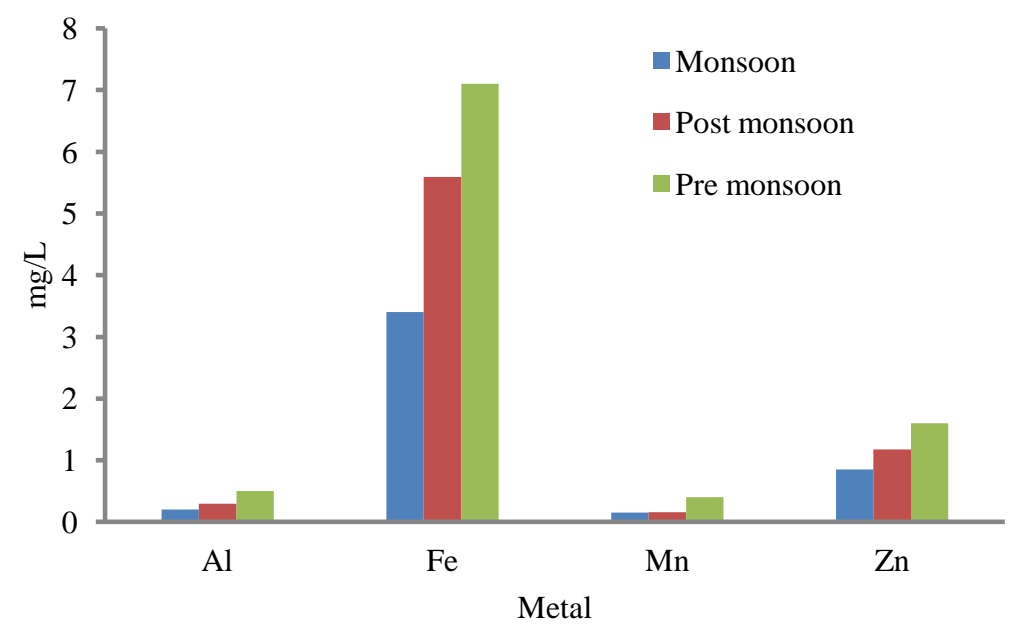

(b)

Figure 5. Seasonal variation of ions and metals in groundwater. 


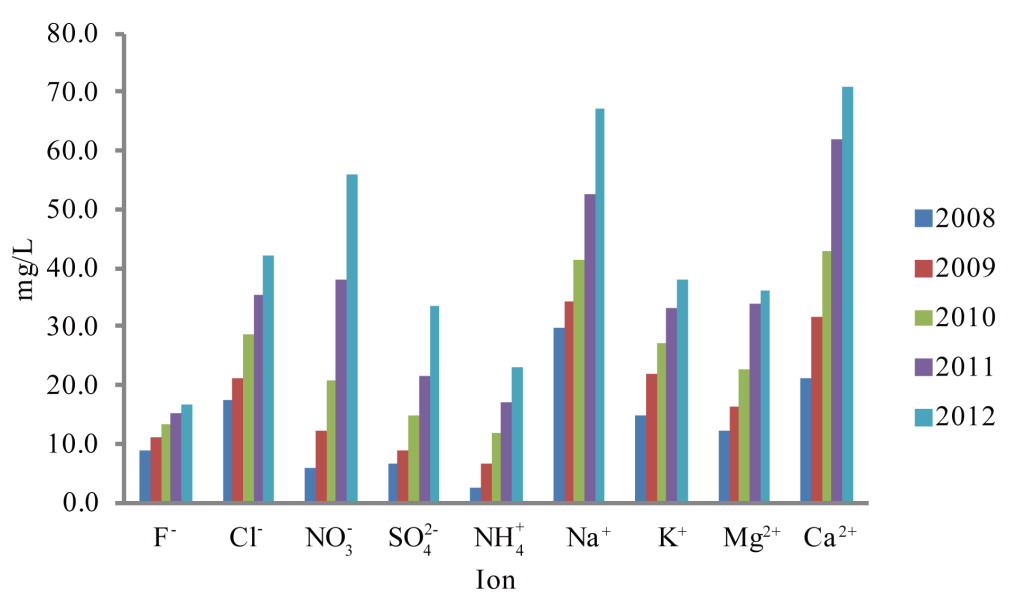

(a)

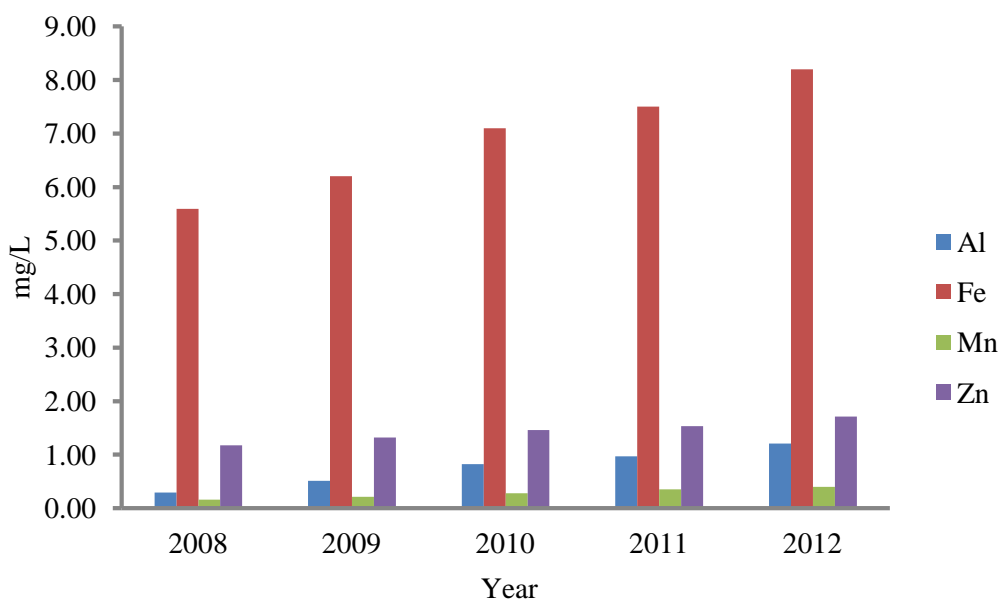

(b)

Figure 6. Temporal variation of ions and metals in groundwater.

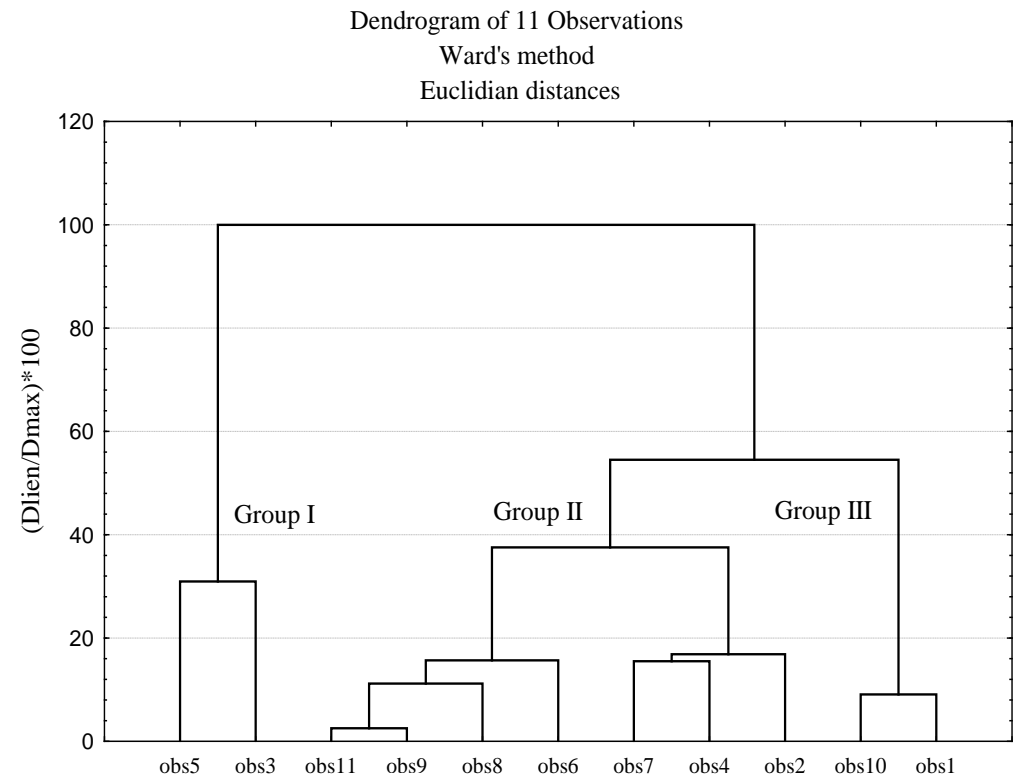

Figure 7. Ward's dendrogram of the sample sites in the study area. 
Table 4. Factor loadings after varimax rotation.

\begin{tabular}{|c|c|c|c|c|c|}
\hline Parameter & Factor-I & Factor-II & Factor-III & Factor-IV & Factor-V \\
\hline $\mathrm{T}\left({ }^{\circ} \mathrm{C}\right)$ & -0.19 & 0.27 & 0.05 & -0.86 & -0.23 \\
\hline $\mathrm{pH}$ & 0.15 & 0.03 & 0.06 & 0.07 & 0.84 \\
\hline EC & 0.14 & -0.05 & 0.02 & 0.02 & 0.97 \\
\hline TDS & 0.74 & -0.05 & 0.07 & 0.02 & 0.65 \\
\hline Water table & -0.04 & 0.05 & 0.88 & 0.34 & -0.15 \\
\hline Depth of tube & -0.21 & 0.57 & 0.65 & -0.36 & -0.02 \\
\hline Life of tube & -0.11 & -0.90 & -0.19 & -0.13 & 0.17 \\
\hline $\mathrm{Al}$ & 0.27 & -0.92 & 0.13 & 0.13 & -0.04 \\
\hline $\mathrm{Fe}$ & -0.14 & -0.50 & 0.20 & 0.59 & -0.39 \\
\hline Mn & 0.63 & 0.50 & 0.07 & 0.12 & 0.42 \\
\hline $\mathrm{Zn}$ & 0.60 & 0.01 & -0.43 & 0.14 & 0.64 \\
\hline $\mathrm{Na}^{+}$ & 0.16 & -0.19 & 0.89 & -0.17 & 0.29 \\
\hline $\mathrm{K}^{+}$ & 0.41 & 0.07 & -0.21 & 0.20 & 0.78 \\
\hline $\mathrm{Mg}^{2+}$ & 0.69 & 0.01 & -0.28 & 0.08 & 0.63 \\
\hline $\mathrm{Ca}^{2+}$ & 0.81 & 0.01 & -0.33 & 0.12 & 0.46 \\
\hline $\mathrm{NH}_{4}^{+}$ & -0.05 & 0.38 & 0.01 & 0.81 & 0.18 \\
\hline $\mathrm{F}^{-}$ & -0.40 & 0.20 & 0.82 & 0.01 & -0.30 \\
\hline $\mathrm{Cl}^{-}$ & 0.92 & -0.09 & 0.17 & -0.05 & 0.27 \\
\hline $\mathrm{NO}_{3}^{-}$ & 0.44 & 0.47 & 0.07 & 0.01 & 0.53 \\
\hline $\mathrm{SO}_{4}^{2-}$ & 0.99 & -0.09 & -0.09 & -0.03 & -0.02 \\
\hline Alkalinity & 0.23 & 0.00 & -0.04 & 0.02 & 0.92 \\
\hline Hardness & 0.76 & 0.01 & -0.31 & 0.11 & 0.54 \\
\hline Eigenvalues & 9.99 & 3.54 & 2.62 & 1.97 & 1.80 \\
\hline \% Explained variance & 45.45 & 16.09 & 11.94 & 8.99 & 8.2 \\
\hline$\%$ Cumulative of variance & 45.45 & 61.54 & 73.48 & 82.47 & 90.67 \\
\hline
\end{tabular}

exchange between $\mathrm{Ca}^{2+}$ and $\mathrm{Na}^{+}$. Ammonium ions with high positive loading value and $\mathrm{T}\left({ }^{\circ} \mathrm{C}\right)$ with a negative loading value were related to Factor-IV. This could highlight the impact of agricultural fertilizers. Factor-V characterized the mineralization of the groundwater and the importance of carbonic acid on the groundwater alkalinity which increased the $\mathrm{pH}$ value.

The $\mathrm{F}^{-}$content of the water had fair positive correlation $(\mathrm{r}=0.6900 .75)$ with the geological characteristics (i.e. water table and depth) of the tube wells likely to $\mathrm{Na}^{+}$and $\mathrm{Fe}(\mathrm{r}=0.2500 .56)$. However, almost all ions had negative correlation with the tube well geological parameters. The $\mathrm{F}^{-}$content with the $\mathrm{pH}$, alkalinity, $\mathrm{HCO}_{3}^{-}$, $\mathrm{Mg}^{2+}$ and $\mathrm{Ca}^{2+}$ values had negative correlation $(\mathrm{r}=-0.2200 .72)$. The $\mathrm{pH}$ value was dependent on $\mathrm{OH}^{-}$concentration rather than $\mathrm{HCO}_{3}^{-}$and $\mathrm{CO}_{3}^{2-}$ concentration. The negative correlation of the $\mathrm{F}^{-}$content with the hardness was expected due to the precipitation of $\mathrm{CaCO}_{3}$. The positive correlation $(\mathrm{r}=0.56)$ of $\mathrm{Na}^{+}$with the $\mathrm{F}^{-}$indicated its release in the ground water from weathering of silicate minerals. The cation exchange $\left(\mathrm{Na}^{+}\right.$for $\left.\mathrm{Ca}^{2+}\right)$ accompanied with anion exchange $\left(\mathrm{OH}^{-}\right.$for $\left.\mathrm{F}^{-}\right)$of mica and clay was expected as important processes in release of $\mathrm{Ca}^{2+}$ and $\mathrm{F}^{-}$. Fluoride ions in the ground water had fair positive correlation only with Fe. While with other 
species, $\mathrm{F}^{-}$had negative correlation. Most of the ions i.e. $\mathrm{Na}^{+}, \mathrm{K}^{+}, \mathrm{Mg}^{2+}, \mathrm{Ca}^{2+}, \mathrm{NH}_{4}^{+}, \mathrm{F}^{-}, \mathrm{Cl}^{-}, \mathrm{NO}_{3}^{-}$and $\mathrm{SO}_{4}^{2-}$ among themselves had positive correlation unlikely to $\mathrm{F}^{-}$.

\subsection{Chemical Characteristics of Dust, Soil and Rock}

The dusts and soils were yellowish colored with mean $\mathrm{pH}$ value $(\mathrm{n}=6)$ of $7.2 \pm 0.5$ and $7.4 \pm 0.6$, respectively. The mean water soluble content $(\mathrm{n}=11)$ of $\mathrm{F}^{-}, \mathrm{Cl}^{-}, \mathrm{NO}_{3}^{-}, \mathrm{SO}_{4}^{2-}, \mathrm{NH}_{4}^{+}, \mathrm{Na}^{+}, \mathrm{K}^{+}, \mathrm{Mg}^{2+}$ and $\mathrm{Ca}^{2+}$ in the soil extracts was found to be $490 \pm 19,1615 \pm 512,417 \pm 55,805 \pm 98,108 \pm 46,3610 \pm 712,1010 \pm 250,502 \pm 51$ and $3118 \pm 276 \mathrm{mg} / \mathrm{kg}$, respectively. The enhanced content of ions in the road dust samples was achieved due to higher anthropogenic stresses, Figure 8. The distribution pattern of the ions in the surface dust and soil had almost similar trend as in the ground water. The $\mathrm{F}^{-}$content in the granite $(\mathrm{n}=6)$ was ranged from $1798-2510$ $\mathrm{mg} / \mathrm{kg}$ with mean value of $2200 \pm 154 \mathrm{mg} / \mathrm{kg}$, respectively, may be due to presence of fluoride minerals i.e. fluorite $\left(\mathrm{CaF}_{2}\right)$, apatite $\left[\mathrm{Ca}_{5}(\mathrm{Cl}, \mathrm{F}, \mathrm{OH})\left(\mathrm{PO}_{4}\right)_{3}\right]$, etc. The $\mathrm{F}^{-}$content in the dust and soil of this region was found to be higher than other regions [34]-[36].

\subsection{Toxicities}

Two types of water: (Na-Ca-Mg- $\mathrm{HCO}_{3}$ and Na-Ca-Mg- $\mathrm{HCO}_{3}-\mathrm{Cl}$ ) was observed in the study area (Figure 9). The majority of groundwater belonged to the Na-Ca-Mg- $\mathrm{HCO}_{3}-\mathrm{Cl}$ type. The water in the studied area becomes turbid when exposed to the air. The tolerance limit of $\mathrm{F}^{-}, \mathrm{Fe}, \mathrm{Mn}$ and $\mathrm{Al}$ in drinking water reported is 1.5, 0.30, 0.10 and $0.03 \mathrm{mg} / \mathrm{L}$, respectively [37] [38]. The water of all tube wells was found to be contaminated with $\mathrm{F}^{-}, \mathrm{Fe}$, $\mathrm{Mn}$ and $\mathrm{Al}$ beyond the permissible limits. The elevated concentration of $\mathrm{F}^{-}$in the urine samples of humans and domestic animals were observed, Table 5. The $\mathrm{F}^{-}$concentration $(\mathrm{n}=6)$ in the urine samples of male(MU), female(FU), cattle(CU), buffalo(BU), sheep(SU) and goat(GU) was ranged from 8.1 - 12, 8.8 - 13, 20 - 29, 22 - 28, 20 - 26 and $43-66 \mathrm{mg} / \mathrm{L}$ with mean value of $9.9 \pm 0.9,11 \pm 1,24 \pm 2,25 \pm 2,23 \pm 2$ and $52 \pm 6 \mathrm{mg} / \mathrm{L}$, respectively. Among them, the highest $\mathrm{F}^{-}$concentration was seen in the GU, may be due to intake of higher the contaminated green food. The sevear dental and skeletal fluorosis in human and domestic animals i.e. cattle, buffalo, sheep and goat were seen, mainly due to intake of fluoride contaminated water.

\section{Conclusion}

The whole environment in the Tamnar block is contaminated with $\mathrm{F}^{-}$at excessive levels. The groundwater was found to be contaminated with $\mathrm{F}^{-}, \mathrm{Fe}, \mathrm{Mn}$ and $\mathrm{Al}$ at levels above permissible limits. The deeper tube well water lie along the stream was contaminated with higher content of $\mathrm{F}^{-}$. The increased fluoride toxicity in the studied area is recorded due to occurrence of relatively lower concentration of the sequestrating agents i.e. $\mathrm{Al}, \mathrm{Mg}$ and $\mathrm{Ca}$, in the water. The groundwater of the Tamnar area was found to be unsuitable for drinking purposes.

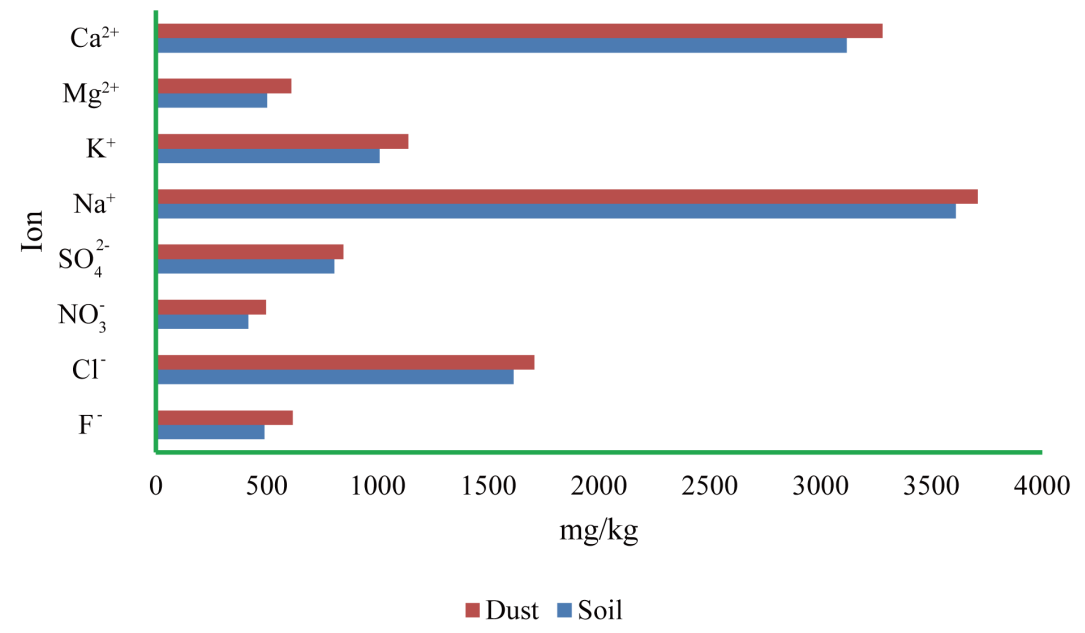

Figure 8. Distribution of water soluble ions in road dust and soil. 


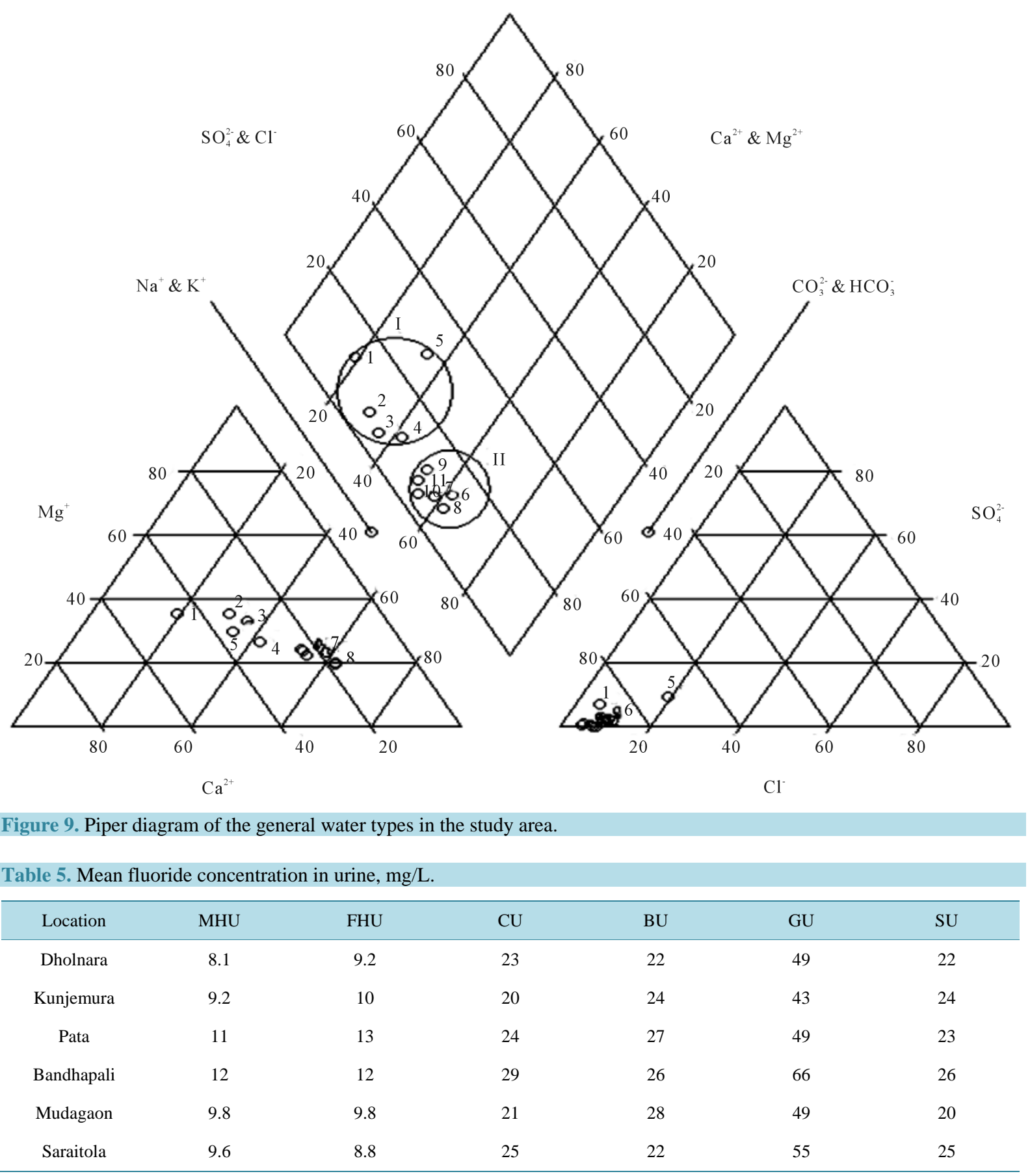

MHU, MFU, CU, BU, GU and SU = Male human, female human, cattle, buffalo, goat and sheep urine.

\section{Acknowledgements}

We are thankful to the Alexander von Humboldt Foundation, Bonn for providing fellowship to one of the authors: KSP for doing some part of this work in the Applied Sciences University, Karlsruhe, Germany.

\section{References}

[1] Manahan, S.E. (2009) Environmental Chemistry, 7th Edition, CRC Press, Boca Raton. Environmental Progress, 21, J13-J14. http://dx.doi.org/10.1002/ep.670210206 
[2] Arlappa, N., Aatif Qureshi, I. and Srinivas, R. (2013) Fluorosis in India: An Overview. International Journal of Research and Development of Health, 1, 97-102. http://www.ijrdh.com/files/11.Fluorosis.pdf

[3] Brindha, K., Rajesh, R., Murugan, R. and Elango, L. (2011) Fluoride Contamination in Groundwater in Parts of Nalgonda District, Andhra Pradesh, India. Environmental Monitoring Assessment, 172, 481-492. http://dx.doi.org/10.1007/s10661-010-1348-0

[4] Dar, M.A., Shankar, K. and Dar, I.A. (2011) Fluorine Contamination in Groundwater: A Major Challenge. Environmental Monitoring Assessment, 173, 955-968. http://dx.doi.org/10.1007/s10661-010-1437-0

[5] Das, B., Talukdar, J., Sharma, S., Gohain, B., Dutta, R.K., Das, H.B and Das, S.C. (2003) Fluoride and Other Inorganic Constituents in Groundwater of Guwahati, Assam, India. Current Science, 85, 657-661. http://www.iisc.ernet.in/currsci/sep102003/657.pdf

[6] Datta, A.S., Chakrabortty, A., De Dalal, S.S., and Lahiri, S.C. (2014) Fluoride Contamination of Underground Water in West Bengal, India. Fluoride, 47, 241-248. http://www.fluorideresearch.org/473/files/FJ2014_v47_n3_p241-248_sfs.pdf

[7] Dutta, R.K., Saikia, G., Das, B., Bezbaruah, C., Das, H.B. and Dube, S.N. (2006) Fluoride Contamination in Groundwater of Central Assam, India. Asian Journal of Water Environmental and Pollution, 3, 93-100.

[8] Hussain, I., Arif, M and Hussain, J. (2012) Fluoride Contamination in Drinking Water in Rural Habitations of Central Rajasthan, India. Environmental Monitoring Assessment, 184, 5151-5158. http://dx.doi.org/10.1007/s10661-011-2329-7

[9] Jha, S.K., Nayak, A.K. and Sharma, Y.K. (2010) Potential Fluoride Contamination in the Drinking Water of Marks Nagar, Unnao District, Uttar Pradesh, India. Environmental Geochemistry and Health, 32, 217-226. http://dx.doi.org/10.1007/s10653-009-9277-y

[10] Kundu, M.C. and Mandal, B. (2009) Assessment of Potential Hazards of Fluoride Contamination in Drinking Groundwater of an Intensively Cultivated District in West Bengal, India. Environmental Monitoring Assessment, 152, 97-103. http://dx.doi.org/10.1007/s10661-008-0299-1

[11] Meenakshi, Garg, V.K., Kavita, Renuka and Malik, A. (2004) Groundwater Quality in Some Villages of Haryana, India: Focus on Fluoride and Fluorosis. Journal of Hazardous Materials, 106, 85-97. http://dx.doi.org/10.1016/j.jhazmat.2003.09.007

[12] Raju, N.J., Dey, S. and Das, K. (2009) Fluoride Contamination in Groundwater of Sonbhadra District, Uttar Pradesh, India. Current Science, 96, 975-985.

[13] Reddy, D.V., Nagabhushanam, P., Sukhij, B.S., Reddy, A.G.S. and Smedley, P.L. (2010) Fluoride Dynamics in the Granitic Aquifer of the Wailapally Watershed, Nalgonda District, India. Chemical Geology, 269, 278-289. http://dx.doi.org/10.1016/j.chemgeo.2009.10.003

[14] Shaji, E., Viju, B.E. and Thambi, D.S. (2007) High Fluoride in Groundwater of Palghat District, Kerala. Current Science, 92, 240-245.

[15] Sharma, B.S., Agrawal, J. and Gupta, A.K. (2011) Emerging Challenge: Fluoride Contamination in Groundwater in Agra District, Utter Pradesh. Asian Journal of Experimental Biological Science, 2, 131-134.

[16] Sankararamakrishnan, N., Sharma, A.K. and Iyengar, L. (2008) Contamination of Nitrate and Fluoride in Ground Water along the Ganges Alluvial Plain of Kanpur District, Uttar Pradesh, India. Environmental Monitoring Assessment, 146, 375-382. http://dx.doi.org/10.1007/s10661-007-0085-5

[17] Singh, V.K., Bikundia, D.S., Sarswat, A. and Mohan, D. (2012) Groundwater Quality Assessment in the Village of Lutfullapur Nawada, Loni, District Ghaziabad, Uttar Pradesh, India. Environmental Monitoring Assessment, 184, 4473-4488. http://dx.doi.org/10.1007/s10661-011-2279-0

[18] Singh, B., Gaur, S. and Garg, V.K. (2007) Fluoride in Drinking Water and Human Urine in Southern Haryana, India. Journal of Hazardous Materials, 144, 147-151. http://dx.doi.org/10.1016/j.jhazmat.2006.10.010

[19] Suthar, S., Garg, V.K., Jangir, S., Kaur, S., Goswami, N. and Singh, S. (2008) Fluoride Contamination in Drinking Water in Rural Habitations of Northern Rajasthan, India. Environmental Monitoring Assessment, 145, 1-6. http://dx.doi.org/10.1007/s10661-007-0011-x

[20] Yadav, J.P., Lata, S., Kataria, S.K. and Kumar, S. (2009) Fluoride Distribution in Ground Water and Survey of Dental Fluorosis among School Children in the Villages of the Jhajjar District of Haryana, India. Environmental Geochemistry and Health, 31, 431-438. http://dx.doi.org/10.1007/s10653-008-9196-3

[21] Viswanathan, G., Jaswanth, A., Gopalakrishnan, S., Siva Ilango, S. and Aditya, G. (2009) Determining the Optimal Fluoride Concentration in Drinking Water for Fluoride Endemic Regions in South India. Science of the Total Environment, 407, 5298-5307. http://dx.doi.org/10.1016/j.scitotenv.2009.06.028

[22] Patel, K.S., Sharma, R., Sahu, B.L., Patel, R.K. and Matini, L. (2014) Groundwater Quality of Rajnandgaon City, India. 
Asian Journal of Water, Environment and Pollution, 11, 31-37.

https://www.deepdyve.com/lp/ios-press/groundwater-quality-of-rajnandgaon-city-india-9r6lmWnUXK

[23] Patel, K.S., Sahu, B.L., Dahariya, N.S., Bhatia, A., Patel, R.K., Matini, L., Sracek, O. and Bhattacharya, P. (2015) Groundwater Arsenic and Fluoride in Rajnandgaon District, Chhattisgarh, Northeastern India. Applied Water Science, In Press.

[24] Beg, M.K., Srivastav, S.K., Carranza, E.J.M. and de Smeth, J.B. (2011) High Fluoride Incidence in Groundwater and its Potential Health Effects in parts of Raigarh District, Chhattisgarh, India. Current Science, 100, 750-754.

[25] Nielsen, D.M. and Nielsen, G. (2006) The Essential Handbook of Ground-Water Sampling. CRC Press, Boca Raton. https://www.crcpress.com/The-Essential-Handbook-of-Ground-Water-Sampling/Nielsen-Nielsen/9781420042788

[26] Carter, M.R. and Gregorich, E.G. (2007) Soil Sampling and Methods of Analysis. 2nd Edition, CRC Press, Boca Raton. https://www.crcpress.com/Soil-Sampling-and-Methods-of-Analysis-Second-Edition/Carter-Gregorich/9780849335860

[27] McQuaker, N.R. and Gurney, M. (1977) Determination of Total Fluoride in Soil and Vegetation Using an Alkali Fusion Selective Ion Electrode Technique. Analytical Chemistry, 49, 53-56. http://dx.doi.org/10.1021/ac50009a022

[28] APHA, American Public Health Association (2005) Standard Methods for the Examination of Water and Wastewater. 21st Edition, American Public Health Association, American Water Works Association, Water Environment Federation, Washington DC. http://www.worldcat.org/oclc/156744115/editions?editionsView=true\&referer=di

[29] Nollet, L.M.L. and De Gelder, L.S.P. (2007) Handbook of Water Analysis. 2nd Edition, CRC Press, Boca Raton. https://www.crcpress.com/Handbook-of-Water-Analysis-Second-Edition/Nollet-De-Gelder/9780849370335

[30] Laaksoharju, M., Skarman, C. and Skarman, E. (1999) Multivariate Mixing and Mass Balance (M3) Calculation, a New Tool for Decoding Hydrogeochemical Information. Applied Geochemistry, 14, 861-871. http://dx.doi.org/10.1016/S0883-2927(99)00024-4

[31] Malinowski, E.R. (1991) Factor Analysis in Chemistry. 2nd Edition, John Wiley \& Sons, New York.

[32] Sharma, M.K. and Jain, C.K. (2006) Multivariate Analysis of Ground Water Quality Date of District Jodhpur, Rajasthan, India. Journal of Environmental Science and Engineering, 48, 271-280.

[33] Rudnick, R.L. and Gao, S. (2003) The Composition of the Continental Crust. Treatise on Geochemistry, 3, 1-64.

[34] Jha, S.K., Nayak, A.K., Sharma, Y.K., Mishra, V.K. and Sharma, D.K. (2008) Fluoride Accumulation in Soil and Vegetation in the Vicinity of Brick fields. Bulletin of Environmental Contamination and Toxicology, 80, 369-373. http://dx.doi.org/10.1007\%2fs00128-008-9391-z

[35] Madhavan, N. and Subramanian, V. (2002) Fluoride in Fractionated Soil Samples of Ajmer District, Rajasthan. Journal of Environmental Monitoring, 4, 821-822. http://dx.doi.org/10.1039/B208151B

[36] Shanwal, A.V., Dahiya, I.S. and Dahiya, D.J. (1989) Soil Fluorine as an Indicator of Profile Development in Yamuna Alluvial Plain India. Fluoride, 22, 119-127.

[37] BIS (2009) Drinking Water-Specification. 2nd Edition, Bureau of Indian Standard, New Delhi. http://bis.org.in/sf/fad/FAD25(2047)C.pdf

[38] WHO (2011) Guidelines for Drinking Water Quality. 4th Edition, World Health Organization, Geneva. http://www.haceclick.com.uy/documentos/GuIa_OMS\%202011_4aEd.pdf 